\title{
INDEKS SEKTOR PERTAMBANGAN: DAMPAK DARI INFLASI, SUKU BUNGA SBI DAN NILAI TUKAR
}

\begin{abstract}
Inflation, SBI Interest Rate, and Exchange Rate are one of the factors that can increase and decrease the Mining Sector Index and ultimately will have an impact on investors' decisions to invest.The purpose of this study was to determine the effect of Inflation, SBI Interest Rate, and Exchange Rate on the Mining Sector Index listed on the Indonesia Stock Exchange in the period 2013-2017. The research method used is descriptive and verification method using multiple linear regression models. The $F$ test is used to identify a decent-value (fix) regression model for testing data, while for the $t$ test (Partial) basically shows how much influence one independent variable (Inflation, SBI Interest Rate, and Exchange Rate) have on the dependent variable (Mining Sector Index). The results showed that the SBI Interest Rate and Exchange Rate variables had a significant negative effect on the Mining Sector Index, while Inflation had no significant effect on the Mining Sector Index.
\end{abstract}

ABSTRAK: Inflasi, Suku Bunga SBI dan Nilai Tukar merupakan salah satu faktor yang dapat menaikkan dan menurunkan Indeks Sektor Pertambangan dan pada akhirnya akan berdampak pada keputusan investor untuk berinvestasi. Tujuan dari penelitian ini adalah untuk mengetahui pengaruh Inflasi, Suku Bunga SBI dan Nilai Tukar terhadap Indeks Sektor Pertambangan yang terdaftar di Bursa Efek Indonesia periode 2013-2017. Metode penelitian yang dilakukan adalah metode deskriptif dan verifikatif dengan menggunakan model regresi linier berganda. Uji $\mathrm{F}$ digunakan untuk mengidentifikasi model regresi yang diestimasi layak (fix) atau tidak layak untuk pengujian data, sedangkan Uji t (Parsial) pada dasarnya menunjukkan seberapa besar pengaruh satu variabel independen (Inflasi, Suku Bunga SBI, dan Nilai Tukar) terhadap variabel dependen (Indeks Sektor Pertambangan). Hasil penelitian menunjukkan Suku Bunga SBI dan Nilai Tukar berpengaruh negatif signifikan terhadap Indeks Sektor Pertambangan, sedangkan Inflasi tidak berpengaruh signifikan terhadap Indeks Sektor Pertambangan.

\section{Dede Hertina $^{1}$}

${ }^{1}$ Fakultas Bisnis \& Manajemen, Universitas Widyatama Jl. Cikutra No.204A, Kota Bandung, Indonesia

Keywords: Inflation, SBI Interest Rate, and Exchange Rate

Kata Kunci: Inflasi, Suku Bunga SBI, dan Nilai Tukar 


\section{Pendahuluan}

Pasar modal memiliki peran besar dalam perekonomian suatu negara, dimana pasar modal dapat menjadi alternatif sumber pembiayaan kegiatan perusahaan. Sumber pembiayaan tersebut dapat melalui penjualan saham maupun penerbitan obligasi oleh perusahaan yang membutuhkan dana. Bagi calon investor dalam melakukan investasi dapat menggunakan harga saham sebagai sinyal investasi. Harga saham merupakan cerminan dari nilai perusahaan bagi para investor, dimana investor akan membuat keputusan dalam membeli suatu saham kemudian menjualnya kembali. Harga saham suatu perusahaan ditentukan oleh tingginya permintaan dan penawaraan saham di pasar modal, apabila permintaan terhadap suatu saham meningkat maka secara tidak langsung harga saham perusahaan tersebut akan meningkat, begitupun sebaliknya. Bursa Efek Indonesia memiliki beberapa indeks sektoral, salah satu sektornya adalah sektor Pertambangan. Sektor Pertambangan merupakan satu dari sepuluh sektor yang terdaftar di Bursa Efek Indonesia yang terdiri dari sub sektor batu bara, minyak dan gas bumi, logam dan mineral lainnya, batu-batuan, dan lain-lain. Perkembangan industri pertambangan sejak dahulu hingga sekarang menjadi primadona di beberapa daerah di Indonesia, sehingga menjadi salah satu tolok ukur pembangunan ekonomi nasional. Kegiatan industri pertambangan dimulai dari eksplorasi dan eksploitasi yang dilakukan hingga puluhan tahun. Oleh sebab itu, industri pertambangan merupakan industri padat modal dan investasi jangka panjang yang membedakan dengan industri-industri lainnya.Sektor Pertambangan mendapatkan perhatian khusus dari pemerintah pusat dan daerah karena dapat menghasilkan pendapatan yang cukup besar. Beberapa daerah di Indonesia yang menjadi pusat eksplorasi dan eksploitasi industri pertambangan, yaitu Papua, Kalimantan, Sulawesi, dan Sumatera dengan hasil pertambangan yang berbeda-beda. Hasil tambang di Indonesia yang melimpah membuat perusahaan-perusahaan besar bermunculan yang bergerak di sektor Pertambangan, sehingga membuat ketertarikan investor lokal maupun asing untuk menanamkan sahamnya. Investasi di sektor Pertambangan dapat meningkatkan pendapatan investor maupun masyarakat di sekitarnya sebab memiliki tingkat return dan profitabilitas yang tinggi.

Fenomena yang dialami sektor Pertambangan terjadi pada tahun 2015 yang cenderung turun yaitu sebesar 1,027.48, jauh berbeda dengan tahun-tahun sebelumnya. Tahun 2015 merupakan tahun penuh tantangan bagi sektor Pertambangan. Hal tersebut terjadi karena harga komoditas yang cenderung fluktuatif seperti harga emas, perak dan lainlain. Perusahaan pertambangan Indonesia pada tahun tersebut selain berjuang mengatasi masalah lemahnya harga komoditas juga menurunnya permintaan dari negara tujuan ekspor batu bara, yaitu Tiongkok dan negara berkembang lainnya, karena sedang mengalami perlambatan ekonomi. Selain itu, terjadinya krisis ekonomi global, seperti ketidakpastian jadwal normalisasi suku bunga The Fed (Bank Sentral Amerika Serikat), krisis utang Yunani, hingga currency wars menyusul keputusan China yang mendevaluasi Yuan karena pelemahan angka pertumbuhan ekonomi di China.

Hal ini menyebabkan penurunan yang signifikan atas kinerja keuangan dan sahamsaham perusahaan pertambangan di Indonesia, yang pada akhirnya akan berimbas pada indeks sektor pertambangan. Naik turunnya indeks sektor Pertambangan mengakibatkan investor cenderung melakukan pertimbangan setelah menganalisis, yang nantinya dijadikan acuan dalam mengambil keputusan investasi pada 
saham. Selain faktor tersebut, masih banyak faktor lain yang dapat mempengaruhi pergerakkan naik turunnya indeks harga saham, diantaranya yang berasal dari faktor eksternal seperti indeks bursa asing negara lain (Dow Jones, Hang Seng, Nikkei, dan lain sebagainya), tren perubahan harga minyak dunia, tren harga emas dunia, kebijakan bank sentral asing, persaingan pasar luar negeri, dan berasal dari faktor internal seperti inflasi, suku bunga SBI, nilai tukar rupiah atau kurs. inflasi dapat menaikkan biaya produksi suatu perusahaan dan dapat membuat daya beli masyarakat menjadi menurun. Penurunan daya beli dan biaya produksi yang tinggi secara tidak langsung akan mempengaruhi kondisi pasar modal. Investor tidak akan tertarik untuk menanamkan modalnya dan permintaan terhadap saham khususnya saham Pertambangan menjadi turun. Penurunan permintaan saham akan menyebabkan harga saham ikut mengalami penurunan (Sembiring, 2016). Jika harga saham perusahaan tambang turun, maka indeks sektor pertambangan pun akan ikut menurun.

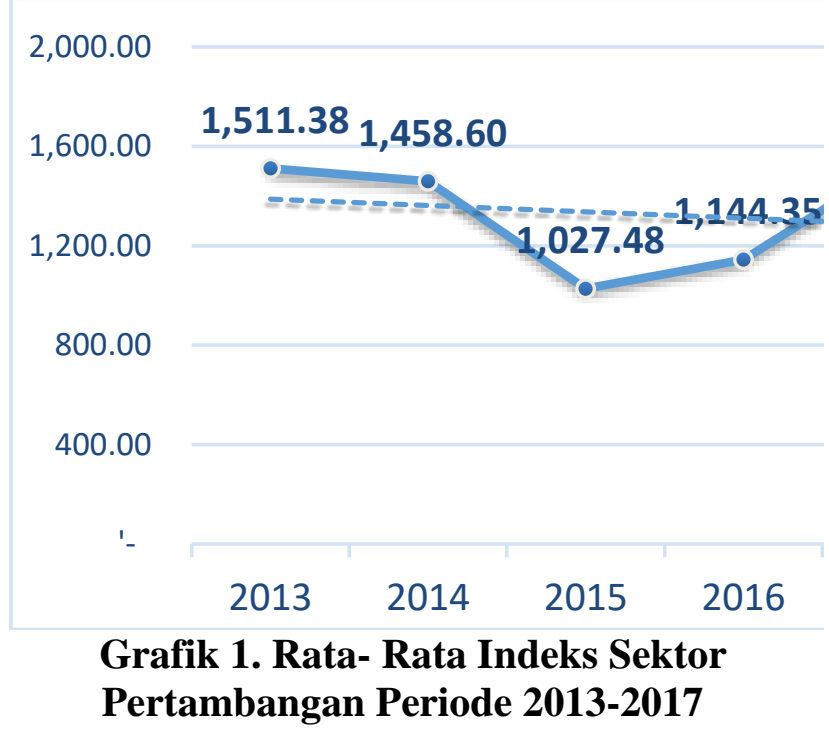

Pertambangan Periode 2013-2017
Dengan tingginya inflasi, maka harga saham cenderung akan turun karena adanya dorongan harga-harga barang yang meningkat sehingga daya beli investor pun akan menurun. Sebaliknya jika inflasi rendah, harga saham akan meningkat karena daya beli investor yang tinggi sehingga permintaan terhadap saham pun meningkat dan mendorong pergerakan harga saham untuk naik (Susanto, 2015). Hal tersebut sejalan dengan yang dijelaskan oleh Tandelilin (2010), peningkatan inflasi secara relatif merupakan sinyal negatif bagi pemodal di pasar modal.

\section{Pengembangan Hipotesis}

Harga saham merupakan salah satu indikator pengelolaan perusahaan. Penting bagi investor untuk mengetahui keadaan perekonomian perusahaan yang berimbas pada harga saham perusahaan. Jika perusahaan mencapai prestasi yang baik, maka saham perusahaan tersebut akan diminati oleh banyak investor. Harga saham yang tinggi akan memberikan keuntungan bagi investor maupun perusahaan, yaitu berupa capital gain, dividen, dan citra yang baik bagi perusahaan.

Fahmi (2015:67) menyatakan harga saham adalah tanda bukti penyertaan kepemilikan modal/dana pada suatu perusahaan. Darmadji dan Fakhrudin (2012:102), berpendapat harga saham merupakan harga yang terjadi di bursa pada waktu tertentu, berubah begitu cepat, tergantung dengan permintaan dan penawaran antara pembeli saham dengan penjual saham. Tandelilin (2010:341) menyatakan harga saham merupakan cerminan dari ekspektasi investor terhadap faktor-faktor earning, aliran kas, dan tingkat return yang disyaratkan investor, yang mana ketiga faktor tersebut juga sangat dipengaruhi oleh kondisi ekonomi makro suatu negara serta kondisi ekonomi global. Jogiyanto (2010:143) berpendapat bahwa harga saham adalah harga yang terjadi 
di pasar bursa pada saat tertentu yang ditentukan oleh pelaku pasar dan ditentukan oleh permintaan dan penawaran saham yang bersangkutan di pasar modal. Dapat disimpulkan bahwa harga saham adalah harga yang terjadi di pasar bursa pada waktu tertentu, yang selalu berfluktuatif karena ditentukan oleh permintaan dan penawaran saham.

Inflasi adalah proses kenaikan harga produk-produk keseluruhan secara terusmenerus yang akan mengakibatkan biaya yang ditanggung perusahaan akan mengalami kenaikan sehingga mengurangi pendapatan. Seperti diketahui bahwa inflasi dapat menaikkan biaya produksi dan dapat membuat daya beli masyarakat akan menjadi menurun. Penurunan daya beli dan biaya produksi yang tinggi secara tidak langsung akan mempengaruhi kondisi pasar modal. Investor tidak akan tertarik untuk menanamkan modalnya dan permintaan terhadap saham menjadi turun. Penurunan permintaan akan menyebabkan harga saham ikut mengalami penurunan (Sembiring, 2017).

Inflasi berpusat pada suatu gejala di mana tingkat harga umum mengalami kenaikan secara terus-menerus. Fahmi (2015:61) menyatakan inflasi merupakan suatu kejadian yang menggambarkan situasi dan kondisi di mana harga barang mengalami kenaikan dan mata uang mengalami pelemahan. Jika kondisi ini terjadi secara terus menerus, akan berdampak pada semakin buruknya kondisi ekonomi secara menyeluruh serta terjadi guncangan pada tatanan stabilitas politik suatu negara. Nopirin (2012:25) mendefinisikan inflasi sebagai proses kenaikan harga-harga umum barang-barang secara terus-menerus. Tandelilin (2010:212) berpendapat bahwa inflasi adalah kecenderungan terjadinya peningkatan harga produk-produk secara keseluruhan. Tingkat inflasi yang tinggi biasanya dikaitkan dengan kondisi ekonomi yang mengalami permintaan atas produk yang berlebih kapasitas terhadap penawaran produknya, sehingga harga-harga cenderung mengalami kenaikan. Dari pendapat beberapa pakar dapat disimpulkan bah Inflasi adalah proses kenaikan harga produk-produk keseluruhan secara terus-menerus yang akan mengakibatkan biaya yang ditanggung perusahaan akan mengalami kenaikan sehingga mengurangi pendapatan.

Dengan tingginya inflasi, maka harga saham cenderung akan turun karena adanya dorongan harga-harga barang meningkat sehingga daya beli investor pun akan menurun, sebaliknya jika inflasi rendah, harga saham akan meningkat karena daya beli investor yang tinggi sehingga permintaan terhadap saham pun meningkat dan mendorong pergerakan harga saham untuk naik (Susanto, 2015). Hasil penelitian yang dilakukan oleh Asih dan Masithah (2016), menyatakan inflasi berpengaruh positif dan signifikan terhadap indeks harga saham gabungan, hal ini sejalan dengan hasil penelitian oleh Saputra dan Bambang (2017), inflasi berpengaruh signifikan terhadap harga saham. Hasil penelitian Anisa dan Ari (2018) menunjukkan bahwa inflasi tidak berpengaruh terhadap indeks harga saham sektor pertambangan. Hal tersebut sejalan dengan hasil penelitian dari Pardede, Raden, dan Sri (2016) serta Agustin (2016) bahwa inflasi tidak berpengaruh signifikan terhadap indeks harga saham sektor pertambangan.

Pengertian suku bunga menurut Sunariyah (2013:80) adalah harga dari pinjaman. Suku bunga dinyatakan sebagai persentase uang pokok per unit waktu. Bunga merupakan suatu ukuran harga sumber daya yang digunakan oleh debitur yang harus dibayarkan kepada kreditur. Astuti (2013) berpendapat bahwa Tingkat suku bunga atau interest rate merupakan rasio pengembalian 
sejumlah investasi sebagai bentuk imbalan yang diberikan kepada investor. Suku bunga dapat menjadi salah satu pedoman investor dalam pengambilan keputusan investasi pada pasar modal. Sebagai alternatif investasi, pasar modal menawarkan suatu tingkat pengembalian (return) pada tingkat risiko tertentu. Tingkat suku bunga menurut Boediono (2014:76) adalah harga dari penggunaan dana investasi (loanable funds). Tingkat suku bunga merupakan salah satu indikator dalam menentukan apakah seseorang akan melakukan investasi atau menabung.

Suku Bunga SBI adalah instrumen yang digunakan BI dalam operasi moneternya, untuk mengarahkan agar suku bunga pasar berada di sekitar BI Rate. SBI Rate, tentunya adalah tingkat suku bunga yang harus dibayar BI. (www.bi.go.id). Suku bunga SBI menurut Kusuma dan Devita (2016) merupakan suku bunga yang dikeluarkan oleh bank sentral untuk mengontrol peredaran uang di masyarakat, dengan kata lain pemerintah melakukan kebijakan moneter. Tingkat suku bunga sektor keuangan yang sering digunakan sebagai panduan atau acuan investor untuk menilai kemampuan pasar uang dalam menghasilkan keuntungan yang optimal adalah tingkat suku bunga Sertifikat Bank Indonesia (SBI). Tingkat suku bunga SBI adalah tingkat pengembalian sejumlah investasi dari surat berharga yang diterbitkan oleh BI sebagai bentuk imbalan yang diberikan kepada investor. (Agustina dan Fitry, 2014). Suku bunga merupakan harga dari penggunaan investasi yang dijadikan sebagai indikator dalam melakukan investasi. Suku bunga yang tinggi akan menyebabkan semakin tingginya bunga pinjaman di industri, dengan demikian maka minat para konsumen menurun dan mengakibatkan rendahnya harga saham pada industri. Suku bunga yang tinggi juga akan meningkatkan minat masyarakat untuk menanamkan dananya di bank daripada menginvestasikannya pada sektor produksi atau industri yang resikonya jauh lebih besar jika dibandingkan dengan menanamkan uang di bank terutama dalam bentuk deposito.

Jika suku bunga naik maka diperkirakan laba bersih perusahaan akan turun, karena naiknya beban bunga, dan begitu juga sebaliknya. Setiap kenaikan atau penurunan laba bersih perusahaan akan tercermin pada harga saham di bursa. Jadi, jika laba bersih perusahaan turun, maka harga saham pada perusahaan tersebut akan cenderung turun, dan apabila laba bersih perusahaan itu naik, maka harga saham pada perusahaan tersebut akan cenderung naik (Kusuma dan Devita, 2016).

Hasil penelitian yang dilakukan oleh Anisa dan Ari (2018), suku bunga SBI berpengaruh dan signifikan terhadap indeks harga saham sektor pertambangan di Indonesia. Hal ini sejalan dengan hasil penelitian oleh Agustin (2016) yang menunjukkan bahwa Suku Bunga SBI berpengaruh signifikan terhadap indeks harga saham sektor pertambangan. Namun menurut hasil penelitian dari Pardede, Raden, dan Sri (2016) menunjukkan bahwa suku bunga (central bank rate) tidak berpengaruh terhadap indeks harga saham sektor pertambangan. Hal tersebut sejalan dengan hasil penelitian dari Agustina dan Fitry (2014), bahwa Tingkat Suku Bunga SBI tidak berpengaruh signifikan terhadap pergerakan harga saham.

Nilai tukar adalah harga mata uang luar negeri terhadap mata uang domestik yang dapat meningkatkan profitabilitas dan harga saham perusahaan. Jika nilai tukar suatu negara tersebut sedang membaik, hal tersebut menjadi daya tarik untuk investor dalam membeli saham pada bursa yang sedang berlangsung karena jika nilai tukar suatu negara sedang melemah investor tidak mau mengambil resiko 
yang tinggi dalam menginvestasikan dananya (Susanto, 2015). Nilai tukar atau kurs satu mata uang terhadap mata uang lainnya merupakan bagian dari proses valuta asing (Manurung, 2016). Nilai tukar akan dapat berubah bila terjadi perubahan selera, perubahan harga barang impor dan barang ekspor, terjadinya inflasi, perubahan suku bunga, dan tingkat pengembalian investasi, serta pertumbuhan ekonomi menurut pandangan Murni (2016:232). Nofiatin (2013) berpendapat Nilai tukar (kurs) adalah sejumlah mata uang lokal yang dibutuhkan untuk membeli satu unit mata uang asing. Menurut Nopirin (2012:163), nilai tukar mata uang merupakan harga di dalam pertukaran dua macam mata uang yang berbeda, akan terdapat perbandingan nilai atau harga antara kedua mata uang tertentu, perbandingan nilai inilah yang disebut kurs exchange rate.

\section{Indikator Nilai Tukar}

Nilai tukar/Kurs tengah BI digunakan untuk mencatat nilai konversi mata uang asing dan sangat dibutuhkan dalam penutupan laporan keuangan perusahaan. Biasanya nilai kurs tengah BI ini digunakan oleh perusahaan asing yang beroperasi di wilayah Indonesia. Nilai Kurs tengah BI USD/IDR menggunakan Kurs Referensi (JISDOR).

$$
\text { KursTengah }=\frac{\text { KursJual }+ \text { KursBeli }}{2}
$$

Hasil penelitian yang dilakukan oleh Habiburrahman (2015), menyatakan nilai tukar berpengaruh positif dan signifikan terhadap indeks harga saham sektor properti. Hal ini sejalan dengan hasil penelitian Pardede, Raden, dan Sri (2016) serta Agustin (2016) hasilnya menunjukkan terdapat pengaruh nilai tukar (kurs) terhadap indeks harga saham sektor pertambangan.
Namun menurut hasil penelitian dari Anisa dan Ari (2018) menyatakan nilai tukar rupiah tidak berpengaruh terhadap indeks harga saham sektor pertambangan. Hal tersebut sejalan dengan hasil penelitian Agustina dan Fitry (2014), bahwa Kurs tidak berpengaruh signifikan terhadap pergerakan harga saham.

Hipotesis

$\mathrm{H}_{1}$ : Terdapat pengaruh Inflasi, Suku Bunga SBI, dan Nilai Tukar terhadap Indeks Sektor Pertambangan

$\mathrm{H}_{2}$ : Terdapat pengaruh Inflasi terhadap Indeks Sektor Pertambangan

$\mathrm{H}_{3}$ : Terdapat pengaruh Suku Bunga SBI terhadap Indeks Sektor Pertambangan

$\mathrm{H}_{4}$ : Terdapat pengaruh Nilai Tukar terhadap Indeks Sektor Pertambangan

\section{Metode, Data dan Analisis}

Penelitian ini menggunakan metode deskriptif dan metode verifikatif. Metode deskriptif adalah studi untuk menemukan fakta dengan interpretasi yang tepat, termasuk didalamnya studi untuk melukiskan secara akurat sifat-sifat dari beberapa fenomena kelompok dan individu, serta studi untuk menentukan frekuensi terjadinya suatu keadaan untuk meminimalisasi bias dan memaksimumkan reabilitas (Nazir, 2011:89). Penelitian yang dilakukan menekankan analisisnya pada data numerik (angka) yang diolah, dengan menggunakan metode penelitian ini akan diperoleh hubungan yang signifikan antar variabel yang diteliti. Sedangkan metode verifikatif digunakan untuk melakukan uji hipotesis melalui pengolahan data dan pengujian data secara statistik. Pemilihan sampel menggunakan purposive sampling. Metode analisis data yang digunakan adalah analisis regresi linier berganda dan analisis koefisien determinasi. 
4. Hasil dan Diskusi

Analisis Regresi Linier Berganda

Untuk mengetahui regresi linier berganda antara inflasi, suku bunga SBI, dan nilai tukar terhadap indeks sektor pertambangan, maka hasil pengujiannya dapat diperoleh pada tabel berikut:

\begin{tabular}{|c|c|c|c|c|c|c|}
\hline \multirow{2}{*}{\multicolumn{2}{|c|}{ Model }} & \multicolumn{2}{|c|}{$\begin{array}{l}\text { Unstandardized } \\
\text { Coefficients }\end{array}$} & \multirow{2}{*}{$\begin{array}{c}\begin{array}{c}\text { Standardi } \\
\text { zed } \\
\text { Coefficient } \\
\mathrm{s}\end{array} \\
\text { Beta }\end{array}$} & \multirow[b]{2}{*}{$t$} & \multirow{2}{*}{$\begin{array}{l}\mathrm{S} \\
\mathrm{i} \\
\mathrm{g}\end{array}$} \\
\hline & & B & $\begin{array}{l}\text { Std } \\
\text { Error }\end{array}$ & & & \\
\hline \multirow[t]{4}{*}{1} & (Constant) & $\begin{array}{r}3520.15 \\
3\end{array}$ & $\begin{array}{r}290.20 \\
2\end{array}$ & & $\begin{array}{r}12 . \\
130\end{array}$ & $\begin{array}{l}0 \\
0 \\
0\end{array}$ \\
\hline & Inflasi & $\begin{array}{r}2631.98 \\
6\end{array}$ & $\begin{array}{r}1825.2 \\
55\end{array}$ & .184 & $\begin{array}{r}1.4 \\
42\end{array}$ & $\begin{array}{l}1 \\
5 \\
5\end{array}$ \\
\hline & $\begin{array}{l}\text { Suku Bunga } \\
\text { SBI }\end{array}$ & $\begin{array}{r}14102.9 \\
97\end{array}$ & $\begin{array}{r}2542.4 \\
50\end{array}$ & -.656 & $\begin{array}{r}5.5 \\
47\end{array}$ & $\begin{array}{l}0 \\
0 \\
0\end{array}$ \\
\hline & Nilai Tukar & -.113 & .020 & -.542 & $\begin{array}{r}- \\
5.6 \\
26\end{array}$ & $\begin{array}{l}0 \\
0 \\
0\end{array}$ \\
\hline
\end{tabular}

a. Dependent Variable: Indeks Sektor Pertambangan

Tabel 1. Analisis Regresi Linier Berganda

Dari tabel 1, diperoleh persamaan regresi sebagai berikut:

$$
\begin{aligned}
Y= & 3.520,153+2.631,986 X_{1} \\
& -14.102,997 X_{2}-0,113 X_{3} \\
& +e
\end{aligned}
$$

Penjelasan dari persamaan:

a. Konstanta sebesar 3.520,153 menyatakan bahwa jika inflasi, suku bunga SBI, dan nilai tukar $=0$ (sama dengan nol) dan tidak ada perubahan, maka indeks sektor pertambangan adalah 3.520,153.

b. Inflasi $\left(\mathrm{X}_{1}\right)$ berpengaruh positif sebesar 2.631,986. Hal ini menunjukkan bahwa peningkatan inflasi sebesar 1 satuan akan menaikkan indeks sektor pertambangan sebesar 2.631,986.

c. Suku Bunga SBI $\left(\mathrm{X}_{2}\right)$ berpengaruh negatif sebesar 14.102,997. Hal ini menunjukkan bahwa peningkatan suku bunga SBI sebesar
1 satuan akan menurunkan indeks sektor pertambangan sebesar 14.102,997.

d. Nilai Tukar $\left(X_{3}\right)$ berpengaruh negatif sebesar 0,113 . Hal ini menunjukkan bahwa peningkatan nilai tukar sebesar 1 satuan akan meningkatkan indeks sektor pertambangan sebesar 0,113 .

Pembahasan Hasil Penelitian

1. Pengaruh Inflasi terhadap Indeks Sektor Pertambangan Yang Terdaftar Di Bursa Efek Indonesia Periode 2013 - 2017.

Koefisien regresi Inflasi sebesar 2.631,986 menunjukkan bahwa setiap peningkatan Inflasi sebesar 1 satuan akan menaikkan Indeks Sektor Pertambangan sebesar 2.631,986. Hasil uji t untuk variabel Inflasi diperoleh dari hasil nilai signifikansi $(0,155 \geq 0,05)$ lebih besar dari 0,05 yang berarti $\mathrm{H}_{\mathrm{a}}$ ditolak dan $\mathrm{H}_{0}$ diterima. Sehingga dapat dikatakan bahwa Inflasi tidak berpengaruh signifikan terhadap Indeks Sektor Pertambangan. Hal tersebut karena inflasi yang besarnya kurang dari $10 \%$ masih bisa diterima oleh pasar karena tingkat inflasi masih dalam kategori merayap atau rendah, yang akan mempengaruhi minat investor untuk berinvestasi (Putong, 2013:422). Apabila inflasi lebih dari 10\%, maka akan menyebabkan tingginya biaya produksi yang disebabkan oleh ketidakefisienan perusahaan, kurs mata uang negara yang bersangkutan, kenaikan harga bahan baku, upah tenaga kerja, dan mengakibatkan turunnya jumlah produksi dan harga jual barang yang tinggi. Harga jual yang semakin tinggi menyebabkan menurunnya daya beli masyarakat. Penurunan daya beli masyarakat ini akan menyebakan menurunnya tingkat probabilitas yang didapatkan perusahaan, sehingga Indeks Sektor Pertambangan kurang diminati oleh investor 
sehingga inflasi merupakan sebuah informasi yang negatif bagi para investor di pasar modal.

Hasil penelitian ini sejalan dengan hasil penelitian yang dilakukan oleh Anisa dan Ari (2018). Hasil dari penelitian ini menunjukkan bahwa inflasi tidak berpengaruh terhadap indeks harga saham sektor pertambangan.. Hal serupa pun diperoleh dari hasil penelitian Pardede, Raden, dan Sri (2016) serta Agustin (2016) yang menyatakan bahwa inflasi tidak berpengaruh signifikan terhadap indeks harga saham sektor pertambangan.

2. Pengaruh Suku Bunga SBI terhadap Indeks Sektor Pertambangan Yang Terdaftar Di Bursa Efek Indonesia Periode 2013 - 2017.

Koefisien regresi Suku Bunga SBI sebesar -14.102,997 menunjukkan bahwa setiap peningkatan Suku Bunga SBI sebesar 1 satuan akan menurunkan Indeks Sektor Pertambangan sebesar 14.102,997. Hasil uji t untuk variabel Suku Bunga SBI diperoleh dari hasil nilai signifikansi $(0,000 \leq 0,05)$ lebih kecil dari 0,05 yang berarti $\mathrm{H}_{0}$ ditolak dan $\mathrm{H}_{\mathrm{a}}$ diterima. Sehingga dapat dikatakan bahwa Suku Bunga SBI berpengaruh signifikan terhadap Indeks Sektor Pertambangan. Nilai koefisien negatif menunjukkan bahwa Suku Bunga SBI memiliki hubungan yang tidak searah dengan Indeks Sektor Pertambangan, artinya setiap peningkatan Suku Bunga SBI akan menurunkan Indeks Sektor Pertambangan. Hal tersebut karena jika suku bunga SBI tinggi maka indeks harga saham sektor pertambangan akan turun karena investor akan menarik modalnya di pasar modal dan menanamkan modalnya untuk tabungan maupun obligasi, sebaliknya jika suku bunga SBI turun maka indeks harga saham sektor pertambangan akan naik karena investor akan menarik modalnya yang ada di perbankan berupa tabungan maupun deposito dan menanamkan modalnya di pasar modal (Agustin, 2016).

Hasil penelitian ini sejalan dengan hasil penelitian yang dilakukan oleh Anisa dan Ari (2018). Hasil dari penelitiannya menunjukkan bahwa Suku Bunga SBI berpengaruh dan signifikan terhadap Indeks harga saham Sektor Pertambangan di Indonesia. Hal serupa pun diperoleh dari hasil penelitian Agustin (2016) yang menyatakan bahwa Suku Bunga SBI berpengaruh signifikan terhadap Indeks harga saham Sektor Pertambangan di Bursa Efek Indonesia.

3. Pengaruh Nilai Tukar terhadap Indeks Sektor Pertambangan Yang Terdaftar Di Bursa Efek Indonesia Periode 2013 - 2017.

Koefisien regresi Nilai Tukar sebesar 0,113 menunjukkan bahwa setiap peningkatan (menguat) Nilai Tukar sebesar 1 satuan akan meningkatkan Indeks Sektor Pertambangan sebesar 0,113. Hasil uji t untuk variabel Nilai Tukar diperoleh dari hasil nilai signifikansi $(0,000 \leq 0,05)$ lebih kecil dari 0,05 yang berarti $\mathrm{H}_{0}$ ditolak dan $\mathrm{H}_{\mathrm{a}}$ diterima. Sehingga dapat dikatakan bahwa Nilai Tukar berpengaruh signifikan terhadap Indeks Sektor Pertambangan. Nilai koefisien negatif menunjukkan bahwa Nilai Tukar memiliki hubungan yang tidak searah dengan Indeks Sektor Pertambangan, artinya setiap peningkatan (menguat) Nilai Tukar akan meningkatkan Indeks Sektor Pertambangan. Hal tersebut artinya semakin kuat kurs rupiah terhadap US \$ (rupiah terapresiasi) maka akan meningkatkan harga saham, dan sebaliknya. Menguatnya kurs rupiah terhadap US \$ akan menurunkan biaya produksi terutama biaya impor bahan baku dan akan diikuti menurunnya tingkat bunga yang berlaku, hal ini akan memberikan dampak positif pada laba perusahaan yang akhirnya menaikkan 
pendapatan per lembar saham (EPS). (Kewal, 2012)

Hasil penelitian ini sejalan dengan hasil penelitian yang dilakukan oleh Pardede, Raden, dan Sri (2016). Hasil dari penelitiannya menunjukkan bahwa terdapat pengaruh Nilai Tukar (kurs) terhadap Indeks harga saham Sektor Pertambangan di Indonesia. Hal serupa juga diperoleh dari hasil penelitian Habiburrahman (2015) yang menyatakan bahwa Nilai Tukar rupiah terhadap dollar AS berpengaruh dan signifikan terhadap Indeks harga saham Sektor Properti.

Kesimpulan, Keterbatasan dan Saran

Kesimpulan

1. Perkembangan Inflasi, Suku Bunga SBI, Nilai Tukar, dan Indeks Sektor Pertambangan di Bursa Efek Indonesia periode 2013-2017 cenderung fluktuatif. Hsil pengujian uji $\mathrm{F}$ menunjukkan Inflasi, Suku Bunga SBI, dan Nilai Tukar berpengaruh signifikan terhadap Indeks Sektor Pertambangan yang terdaftar di Bursa Efek Indonesia periode 2013-2017.

2. Berdasarkan hasil pengujian hipotesis menggunakan uji t menunjukkan bahwa Inflasi tidak berpengaruh signifikan terhadap Indeks Sektor Pertambangan yang terdaftar di Bursa Efek Indonesia periode 2013-2017.

3. Berdasarkan hasil pengujian hipotesis menggunakan uji $\mathrm{t}$ menunjukkan bahwa Suku Bunga SBI memiliki pengaruh yang negatif dan signifikan terhadap Indeks Sektor Pertambangan yang terdaftar di Bursa Efek Indonesia periode 2013-2017.

Berdasarkan hasil pengujian hipotesis menggunakan uji t menunjukkan bahwa Nilai Tukar memiliki pengaruh yang negatif dan signifikan terhadap Indeks Sektor Pertambangan yang terdaftar di Bursa Efek Indonesia periode 2013-2017.
Keterbatasan dan Saran

1. Bagi investor, penelitian ini diharapkan menjadi informasi yang dapat dijadikan sebagai bahan pertimbangan dalam pengambilan keputusan berinvestasi, khususnya pada Indeks Sektor Pertambangan karena cenderung kuat pengaruhnya terhadap pasar modal di Indonesia. Selain itu, para investor juga harus memperhatikan isu-isu atau faktorfaktor yang dapat mempengaruhi pergerakan Indeks Sektor Pertambangan, seperti Suku Bunga SBI dan Nilai Tukar rupiah atau kurs.

2. Bagi penelitian selanjutnya diharapkan untuk menggunakan data harian agar memperoleh hasil penelitian yang lebih akurat, yaitu menggunakan indeks saham selain Indeks Sektor Pertambangan, seperti Indeks LQ45, Indeks Sektoral lainnya, Jakarta Islamic Index (JII), Indeks Kompas 100, Indeks BISNIS-27, Indeks SRIKEHATI, Indeks Papan Utama, Indeks Papan Pengembangan, dan Indeks Individual sehingga mampu melihat gambaran yang lebih lengkap mengenai kondisi pasar modal di Indonesia, dan disarankan juga agar menggunakan faktorfaktor lainnya yang dapat mempengaruhi pergerakkan Indeks Sektor Pertambangan, seperti jumlah uang yang beredar, harga minyak dunia, pertumbuhan ekonomi, kondisi perekonomian global, harga sejumlah komoditas, permintaan pasar, indeks bursa asing negara lain (Dow Jones, Hang Seng, Nikkei, dan lain sebagainya), harga emas dunia, kebijakan Bank Sentral asing, dan lain sebagainya. 


\section{DAFTAR PUSTAKA}

Agustin, Shinta. 2016. Pengaruh Kurs USD, Inflasi, dan Suku Bunga SBI Terhadap Indeks Harga Saham Sektor Pertambangan di Bursa Efek Indonesia. eJournal Administrasi Bisnis, Volume 4, Nomor 2, 2016 : 550 - 562

Agustina dan Fitry Sumartio. 2014. Analisa Faktor-Faktor Yang Mempengaruhi Pergerakan Harga Saham Pada Perusahaan Pertambangan. Jurnal Wira Ekonomi Mikroskil, Volume 4, Nomor 01, April 2014.

Amarasinghe. 2015. Dynamic Relationship Between Interest Rate and Stock Price: Empirical Evidence from Colombo Stock Exchange. International Journal of Business and Social Science Vol. 6, No. 4; April 2015.

Anisa, Ika dan Ari. 2018. Pengaruh Ekonomi Makro dan Harga Komoditas Tambang Dunia terhadap Indeks Harga Saham Sektor Pertambangan di Indonesia. Jurnal Administrasi Bisnis (JAB) Vol. 56 No.1 Maret 2018.

Arikunto, Suharsimi. 2010. Prosedur Penelitian Suatu Pendekatan Praktek. Jakarta: Rineka Cipta.

Asih, Ni Wayan Sri dan Masithah Akbar. 2016. Analisis Pengaruh Inflasi, Suku Bunga, Nilai Tukar (Kurs, dan Pertumbuhan Produk Domestik Bruto (Pdb) Terhadap Indeks Harga Saham Gabungan (IHSG) Studi Kasus Pada Perusahaan Properti yang Terdaftar di Bursa Efek Indonesia. Jurnal Manajemen dan Akuntansi, Volume 17 Nomor 1, April 2016.

Astuti, Ria, Apriatni E.P dan Hari Susanta. 2013. Analisis Pengaruh Tingkat Suku Bunga (SBI), Nilai Tukar (Kurs) Rupiah, Inflasi, dan Indeks Bursa Internasional Terhadap IHSG (Studi Pada IHSG di BEI
Periode 2008-2012). Diponegoro Journal Of Social And Politic Of Science.

Boediono. 2014. Seri Sinopsis Pengantar Ilmu Ekonomi No. 5 Ekonomi Makro. Yogyakarta: BPFE UGM.

Darmadji, Tjiptono dan H.M. Fakhruddin, 2012. Pasar Modal di Indonesia Pendekatan Tanya Jawab. Edisi Ketiga. Jakarta: Salemba Empat.

Fahmi, Irham. 2015. Manajemen Investasi Teori dan Soal Jawab. Edisi 2. Jakarta: Salemba Empat.

Fahmi, Irham dan Yovi L. Hadi. 2011. Teori Portofolio dan Analisis Investasi. Bandung: Alfabeta.

Geetha, Caroline, Rosle Mohidin, Vivin Vincent Chandran, dan Victoria Chong. 2011. The Relationship Between Inflation And Stock Market: Evidence From Malaysia, United States And China. International Journal of Economics and Management Sciences Vol. 1, No. 2, 2011.

Ghozali, Imam. 2016. Aplikasi Analisis Multivariete Dengan Program IBM SPSS 23. Edisi 8. Semarang: Badan Penerbit Universitas Diponegoro.

Habiburrahman. 2015. Analisis Pengaruh Nilai Tukar Rupiah dan Inflasi Terhadap Indeks Harga Saham Sektor Properti di Bursa Efek Indonesia. Jurnal Manajemen dan Bisnis Vol. 5 No. 2 April 2015: 112 -129.

Hadi, Nor. 2013. Pasar Modal: Acuan Teoritis dan Praktis Investasi di Instrumen Keuangan Pasar Modal. Yogyakarta: Graha Ilmu.

Harjito, Agus dan Martono. 2012. Manajemen Keuangan. Edisi ke-2. Yogyakarta: Ekonisia.

Indriantoro, Nur dan Supomo. 2014. Metodologi Penelitian Bisnis untuk Akuntansi \& Manajemen. Yogyakarta: BPFE Yogyakarta. 
Jogiyanto, Hartono. 2010. Teori Portofolio dan Analisis Investasi. Yogyakarta: BPFE.

Kalyanaraman, Lakshmi dan Basmah Al Tuwajri. 2014. Macroeconomics Forces and Stock Prices: Some Empirical Evidence from Saudi Arabia. International Journal of Financial Research Vol. 5, No. 1; 2014.

Kamaludin. 2011. Manajemen Keuangan Konsep Dasar dan Penerapannya. Bandung: Mandar Maju.

Kasmir. 2010. Pengantar Manajemen Keuangan. Edisi Kedua Cetakan Ketiga. Jakarta: Kencana Prenada Media Group.

Kewal, Suramaya Suci. 2012. Pengaruh Inflasi, Suku Bunga, Kurs, dan Pertumbuhan PDB Terhadap Indeks Harga Saham Gabungan. Jurnal Economia, Volume 8, Nomor 1, April 2012.

Kusuma Wardani, Dewi dan Devita Fajar Tri Andarini. 2016. Pengaruh Kondisi Fundamental, Inflasi, dan Suku Bunga Sertifikat Bank Indonesia Terhadap Harga Saham (Study Kasus Pada Perusahaan Real Estate dan Property yang Terdaftar di Bursa Efek Indonesia Tahun 2010-2013). Jurnal Akuntansi Vol. 4 No. 2, Desember 2016.

Manurung, Ria. 2016. Pengaruh Inflasi Suku Bunga dan Kurs terhadap Indeks Harga Saham Gabungan pada Bursa Efek Indonesia. Jurnal Ekonom, Vol. 19, No. 4.

Murni, Asfia. 2016. Ekonomi Makro Edisi Revisi. Bandung: PT Refika Aditama.

Nazir, Mohammad. 2011. Metode Penelitian. Jakarta: Ghalia Indonesia.

Ningrum, Sasi Ngati. 2013. Analisis Pengaruh PBV, ROE, Nilai Tukar Dollar As dan Inflasi terhadap Harga Saham Perusahaan Consumer Goods yang Terdaftar di Bursa Efek Indonesia Periode 2001-2010.
Nofiatin, Ike, dkk. 2013. Hubungan Inflasi, Suku Bunga, Produk Domestik Bruto, Nilai Tukar, Jumlah Uang Beredar, dan Indeks Harga Saham Gabungan 88 (IHSG). Jurnal Aplikasi Manajemen Vol. 11. No.2, Juni 2013.

Nopirin. 2012. Pengantar Ilmu Ekonomi Mikro Makro. Yogyakarta: BPFE Yogyakarta.

Pardede, Noel, Raden Rustam Hidayat, dan Sri Sulasmiyati. 2016. Pengaruh Harga Minyak Mentah Dunia, Inflasi, Suku Bunga (Central Bank Rate), dan Nilai Tukar (Kurs) Terhadap Indeks Harga Saham Sektor Pertambangan di Asean (Studi Pada Indonesia, Singapura, dan Thailand Periode Juli 2013-Desember 2015). Jurnal Administrasi Bisnis (JAB) Vol. 39 No.1 Oktober 2016.

Putong, Iskandar. 2013. Economics Pengantar Mikro dan Makro. Jakarta: Mitra Wacana Media.

Riduwan dan Kuncoro. 2012. Pengantar Statistika. Cetakan ke-5. Bandung: Alfabeta.

Rohmanda, Deny, Suhadak, dan Topowijono. 2014. Pengaruh Kurs Rupiah, Inflasi dan BI Rate Terhadap Harga Saham (Studi Pada Indeks Sektoral Bursa Efek Indonesia Periode 2005-2013). Jurnal Administrasi Bisnis (JAB) Vol. 13 No. 1 Agustus 2014

Santoso, Singgih. 2012. Analisis SPSS pada Statistik Parametrik. Jakarta: PT Elex Media Komputindo.

Saputra, Eri dan Bambang Hadi Santoso. 2017. Pengaruh Nilai Tukar Mata Uang, Inflasi, dan Suku Bunga Terhadap Harga Saham Sektor Properti. Jurnal Ilmu dan Riset Manajemen Volume 6, Nomor 5, Mei 2017.

Sembiring, Masta. 2016. Analisis Pengaruh Pertumbuhan Ekonomi dan Inflasi Terhadap Harga Saham Pada 
Perusahaan Real Estate dan Property Yang Terdaftar di Bursa Efek Indonesia Periode 2011 - 2015. Jurnal Ilmu Ekonomi dan Studi Pembangunan, Vol 17, No 1.

Sugiyono. 2015. Metode Penelitian Pendidikan (Pendekatan Kuantitatif, Kualitatif dan $R \& D)$. Bandung: Alfabeta.

Sugiyono. 2014. Metodologi Penelitian Bisnis. Bandung: Alfabeta.

Sugiyono. 2010. Metodologi Penelitian Kuantitatif \& RND. Bandung: Alfabeta.

Sunariyah. 2013. Pengantar Pengetahuan Pasar Modal. Edisi 6. Yogyakarta: UPP STIM YKPN.

Susanto, Bambang. 2015. Pengaruh Inflasi, Bunga dan Nilai Tukar Terhadap Harga Saham (Studi Pada : Perusahaan Sektor Properti dan Real Estate Tercatat BEI). Jurnal Aset (Akuntansi Riset), 7 (1), 2015. Suselo, Dedi, Atim Djazuli, dan Nur Khusniyah Indrawati. 2015. Pengaruh Variabel Fundamental dan Makro Ekonomi terhadap Harga Saham (Studi pada Perusahaan yang Masuk dalam Indeks LQ45). Jurnal Aplikasi Manajemen Volume 13 Nomor 1 Maret 2015.

Sutrisno. 2012. Manajemen Keuangan Teori Konsep \& Aplikasi. Edisi Pertama Cetakan Kedelapan. Yogyakarta: Ekonisia.

Tandelilin, Eduardus. 2010. Portofolio dan Investasi : Teori dan Aplikasi. Edisi 1. Yogyakarta: Kanisius. 